Manuscript received March 22, 2016; accepted for publication June 1, 2016; published online August 11, 2016.

\footnotetext{
Technische Universität Wien, Inst. of Chemical Technologies and Analytics, Vienna, A-1060, Austria

2 Technische Universität Wien, Inst. of Chemical Technologies and Analytics, Vienna, A-1060, Austria (Corresponding author), e-mail: roland.haubner@tuwien.ac.at

${ }^{3}$ Univ. of Cantabria, Dept. of Materials Science and Engineering, Santander, 39004 Spain
}

J. Böhm, ${ }^{1}$ P. Linhardt, ${ }^{1}$ S. Strobl, ${ }^{1}$ R. Haubner, ${ }^{2}$ and M. V. Biezma ${ }^{3}$

\section{Microstructure of a Heat Treated Nickel-Aluminum Bronze and Its Corrosion Behavior in Simulated Fresh and Sea Water}

\section{Reference}

Böhm, J., Linhardt, P., Strobl, S., Haubner, R., and Biezma, M. V., "Microstructure of a Heat Treated Nickel-Aluminum Bronze and Its Corrosion Behavior in Simulated Fresh and Sea Water," Materials Performance and Characterization, Vol. 5, No. 5, 2016, pp. 689-700, http://dx.doi.org/10.1520/MPC20160029. ISSN 2165-3992

\section{ABSTRACT}

Nickel-aluminum bronzes (NAB) are a family of alloys with excellent mechanical and corrosion resistance properties, even in highly corrosive environments, attributed to the complex as-cast microstructures. Heat treatment, in-service conditions or welding procedures induce microstructural transformations resulting in changes of the properties. To evaluate the corrosion behavior of one selected NAB alloy, different heat treatments were performed and the relation between microstructural changes and corrosion behavior was studied. Under common casting conditions, CuAl10Fe5Ni5 bronze consists of the $\alpha$-phase, $\beta$-phase, and several intermetallic phases, collectively referred to as $\kappa$-phases. The microstructures of the as-cast and heat treated samples were characterized by metallographic methods. After grinding and polishing, the samples were etched with $\mathrm{FeCl}_{3}$-as well as $\mathrm{Cu}\left(\mathrm{NH}_{4}\right)_{2} \mathrm{Cl}_{4}$-solutions and examined by light optical and scanning electron microscopy. Finally, electrochemical corrosion tests of both as-cast and heat treated samples were carried out in simulated fresh water and sea water under potentiostatic conditions. Four specimens of each sample type were polarized simultaneously at different potentials for $70 \mathrm{~h}$. These specimens were used to study the corrosion progress of the different specific microstructural features and constituents by metallographic investigations. 
FIG. 1

Cu-Al- 5 wt. \% Ni-5 wt. \% Fe phase diagram modified from Ref. [1]. The blue line indicates the Al concentration of the alloy investigated. Red lines indicate the various temperatures for the heat treatments.

\section{Keywords}

nickel-aluminum bronze, heat treatment, metallography, microstructure, electrochemistry, corrosion test

\section{Introduction}

Nickel-aluminum bronze (NAB) is a family of alloys widely used to produce cast components for marine applications owing to its excellent corrosion resistance in sea water. The microstructure of the alloy is determined by the cooling process during casting and may change by heat input, e.g., from welding, grinding or other sources, resulting in phase transformations.

Various data, like equilibrium diagrams (Fig. 1) [1-3] or microstructural analysis [4] of NAB alloys, are available in literature.

During solidification of a bronze melt with 9 wt. \% Al, a copper solid solution, referred to as $\beta$-phase, is formed, and in this $\beta$-phase, the other alloying elements are dissolved. Cooling below $940^{\circ} \mathrm{C}\left(1724^{\circ} \mathrm{F}\right)$ causes the $\beta$-phase to decompose into $\alpha$-phase and $\kappa$-phases. Between 940 and $800^{\circ} \mathrm{C}\left(1724\right.$ and $\left.1472^{\circ} \mathrm{F}\right)$, a ternary phase region with $\alpha$-, $\beta$-, and $\kappa$-phases exists, and below $800^{\circ} \mathrm{C}\left(1472^{\circ} \mathrm{F}\right)$ only $\alpha$ - and $\kappa$-phases are present in NAB microstructure (Fig. 1). Particularly $\kappa$-phases show different morphologies and variable compositions between $\mathrm{Fe}_{3} \mathrm{Al}$ and $\mathrm{NiAl}$ [5-7]. During quenching from $1000^{\circ} \mathrm{C}\left(1832^{\circ} \mathrm{F}\right)$ to room temperature, the formation of a

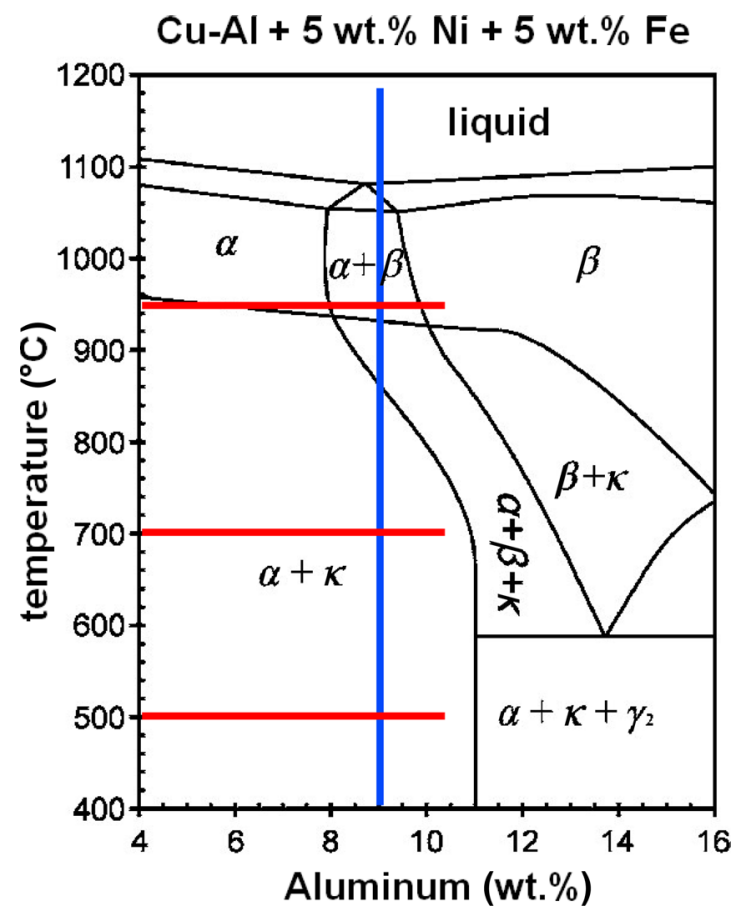


TABLE 1

Chemical composition of CuAl10Fe5Ni5-C (\%wt). Analyzed data (average from three measurements) and nominal composition according to EN-1982.

\begin{tabular}{lllllllllr}
\hline Element & \multicolumn{1}{c}{$\mathrm{Cu}$} & $\mathrm{Zn}$ & $\mathrm{Mn}$ & $\mathrm{Fe}$ & $\mathrm{Al}$ & $\mathrm{Ni}$ & $\mathrm{Sn}$ & $\mathrm{Pb}$ & $\mathrm{Si}$ \\
\hline wt. \% & 80.53 & 0.07 & 1.16 & 4.46 & 8.96 & 4.60 & 0.050 & 0.010 & 0.163 \\
EN-1982 wt. \% & $76.0-83.0$ & $<0.5$ & $<3.0$ & $4.0-5.5$ & $8.5-10.5$ & $4.0-6.0$ & $<0.1$ & $<0.03$ & $<0.1$ \\
\hline
\end{tabular}

martensitic phase, referred to as $\beta^{\prime}$, is described. After a subsequent heat treatment, the $\beta^{\prime}$-phase decomposes into fine-grained $\alpha$ - and $\kappa$-phases [7].

The corrosion behavior of NAB in sea water has been repeatedly studied [8-12], mostly related to as-cast material. Its excellent resistance to high chloride environment is based on formation of a passivating layer, dominated by oxides of copper and aluminum. The multiphase structure bears the risk of dealloying or selective corrosion of the most reactive (anodic) phases. In particular, crevice conditions create a high risk of phase selective corrosion along lamellar $\kappa_{\text {III }}$-phase [13]. Conversely, corrosion of $\mathrm{NAB}$ in fresh water does not appear to be much discussed in literature; apparently it is not of great technical relevance. Nevertheless, a specific case of NAB corrosion in river water has drawn our attention to this topic [14].

Based on these considerations, the influence of heat treatment on the NAB's microstructure and its influence on the corrosion behavior in fresh and seawater are the objectives of this investigation.

\section{Experimental Procedures}

An ingot of NAB CuAl10Fe5Ni5-C (according to EN-1982 [15]) was used for the investigations. The chemical composition analyzed by X-ray fluorescence (XRF) is provided in Table 1. The ingot was cut and plates of 50 by 25 by $20 \mathrm{~mm}^{3}$ in size were used for heat treatment experiments. In this work, the material in the as-cast state was designated AC, see Table 2.

\section{HEAT TREATMENT OF THE BRONZE}

Various heat treatments were carried out in a muffle-type furnace. To prevent oxidation, the NAB samples were embedded in graphite. The first heat treatment was performed at $950^{\circ} \mathrm{C}\left(1742^{\circ} \mathrm{F}\right)$ for $1 \mathrm{~h}$. The specimens were cooled using different cooling rates: one sample was cooled in air (sample T1) and others were water

TABLE 2

List of samples, parameters of heat treatments and results of hardness measurements.

\begin{tabular}{|c|c|c|c|c|c|c|c|c|c|}
\hline \multirow[b]{2}{*}{ Sample } & \multicolumn{4}{|c|}{ 1st Heat Treatment } & \multicolumn{4}{|c|}{ 2nd Heat Treatment } & \multirow[b]{2}{*}{ HV5 } \\
\hline & $\left({ }^{\circ} \mathrm{C}\right)$ & $\left({ }^{\circ} \mathrm{F}\right)$ & Duration & Cooling & $\left({ }^{\circ} \mathrm{C}\right)$ & $\left({ }^{\circ} \mathrm{F}\right)$ & Duration & Cooling & \\
\hline $\mathrm{AC}$ & & & Cast & & - & & - & - & 160 \\
\hline T0 & 950 & 1742 & $1 \mathrm{~h}$ & water & - & & - & - & 232 \\
\hline $\mathrm{T} 1$ & 950 & 1742 & $1 \mathrm{~h}$ & air & - & & - & - & 183 \\
\hline $\mathrm{T} 2$ & 950 & 1742 & $1 \mathrm{~h}$ & water & 700 & 1292 & 1 day & water & 197 \\
\hline T3 & 950 & 1742 & $1 \mathrm{~h}$ & water & 500 & 932 & 1 day & water & 232 \\
\hline
\end{tabular}


quenched (samples T0, T2, T3). The second heat treatment was performed at 700 or $500^{\circ} \mathrm{C}\left(1292\right.$ or $\left.932^{\circ} \mathrm{F}\right)$ for 1 day after water quenching (samples T2, T3). Table 2 summarizes the parameters for all types of samples. Finally, small sheets, of approximately 20 by 20 by $3 \mathrm{~mm}^{3}$ in size, were cut and ground with 600 grit SiC for electrochemical corrosion tests.

\section{METALLOGRAPHIC PREPARATION}

The various samples were sectioned with a cut-off machine and warm embedded in phenolic resin. Preparation started with 320 grit $\mathrm{SiC}$ for plane grinding, followed by fine grinding and polishing with 9,3,1 $1 \mu \mathrm{m}$ diamond suspensions and finally with $0.05 \mu \mathrm{m}$ alumina suspension. To reveal the microstructures, $\mathrm{FeCl}_{3^{-}}$and cupric ammonium chloride $\left(\mathrm{NH}_{4}\right)_{2} \mathrm{CuCl}_{4} \cdot 2 \mathrm{H}_{2} \mathrm{O}$-solutions were used [16].

Metallographic investigations were performed with a light optical microscope (LOM) and a FEI QUANTA $200 \mathrm{~K}$ scanning electron microscope (SEM), equipped with energy dispersive X-ray analysis (EDX). Images were taken in back scattered electron (BSE) mode.

Vicker's hardness measurements HV5 were carried out to evaluate the changes in mechanical properties caused by the heat treatments (Table 2).

\section{ELECTROCHEMICAL CORROSION TESTS}

Simulated sea water (SSW) and simulated fresh water (SFW) were used as electrolytes in the tests. SSW was prepared according to the standard DIN 50,905-4, section 4.1. by dissolving $1 \mathrm{mmol} \mathrm{NaHCO}_{3}$ and $0.5 \mathrm{mmol} \mathrm{Na}_{2} \mathrm{SO}_{4}$ per liter distilled water, SFW was prepared, which is characterized by chloride free, buffered $(60 \mathrm{mg} / \mathrm{L} \mathrm{bicar-}$ bonate), and sulfate dominated $(48 \mathrm{mg} / \mathrm{L}$ ). This composition was chosen on the basis of experiences from a failure analysis reported previously [14].

The saturated calomel electrode $\left(\mathrm{SCE}, 0 \mathrm{mV}_{\mathrm{SCE}}=+242 \mathrm{mV}_{\mathrm{H}}\right)$ was used as reference electrode in all tests and all potentials is referred to SCE.

Potentiostatic measurements were carried out in a cylindrical container (ca. $300 \mathrm{~mm}$ diameter) serving as test cell and filled with $6 \mathrm{~L}$ of electrolyte. A cylinder made from stainless steel mesh was placed inside along the container wall, serving as counter electrode. The reference electrode was inserted from top in the center of the container. For each test, four specimens, serving as working electrodes, were contacted by clamping to suitably bent stainless steel wires and placed symmetrically around the reference electrode. The four specimens were polarized to $+52,+150$, +263 , and $+368 \mathrm{mV}_{\mathrm{SCE}}$, respectively, in SFW. In SSW, the four specimens were polarized to $-262,-211,-156$, and $-104 \mathrm{mV}_{\mathrm{SCE}}$. The lowest of these values was estimated being close to the free corrosion potential of the NAB in the corresponding electrolyte. Polarization was controlled by a multichannel potentiostat (Octopoti, home made [17]), hooked to a data acquisition system logging the individual currents up to $>70 \mathrm{~h}$.

\section{Results and Discussions}

\section{METALLOGRAPHY OF THE HEAT TREATED NAB ALLOY}

For the as-cast NAB, Sample AC, the detailed manufacture parameters, e.g., cooling rate, are unknown. The microstructure is determined by melt solidification and solid 
FIG. 2 As cast NAB microstructures (Sample AC). LOM pictures after etching with $\mathrm{Fe}_{3} \mathrm{Cl}$ and $\mathrm{Cu}\left(\mathrm{NH}_{4}\right)_{2} \mathrm{Cl}_{4}$ solutions, and SEM-BSE image.
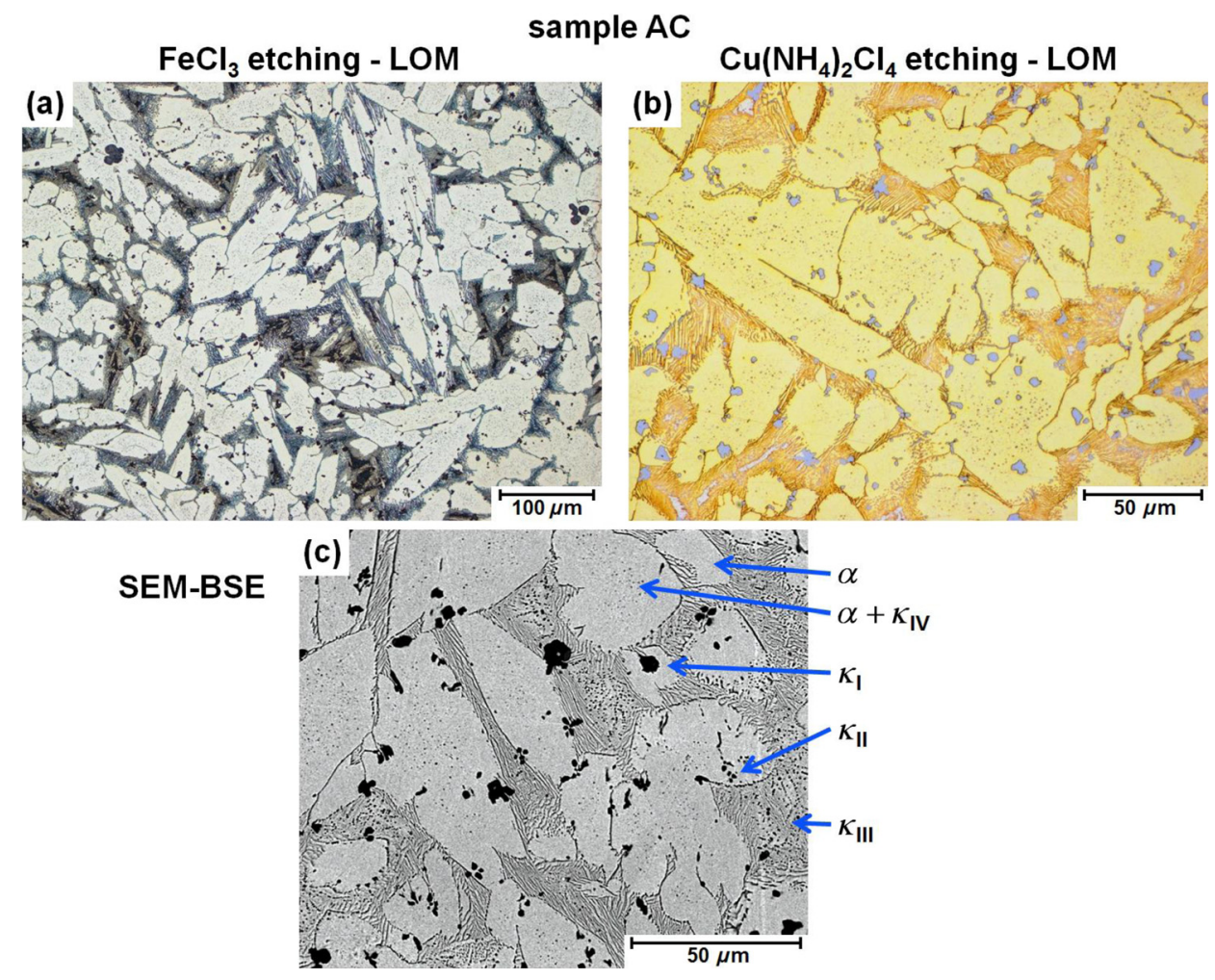

state transformations, thus highly governed by the crystallization of $\alpha$ - and $\beta$-phase from the melt, while the alloying elements tend to segregate according to their diffusion coefficients (Fig. 1). The $\alpha$-phase contains more Ni but less $\mathrm{Al}$ and Fe, contrary $\beta$ contains more $\mathrm{Al}$ and $\mathrm{Fe}$ but less Ni. Below $940^{\circ} \mathrm{C}\left(1724^{\circ} \mathrm{F}\right)$ the $\beta$-phase starts to decompose into $\alpha$ and $\kappa$ phases and at room temperature only these phases exist.

First, coarse, spheroidal $\kappa_{\mathrm{I}}$ precipitates $\left(\mathrm{Fe}_{3} \mathrm{Al}\right)$ are formed, followed by the finer $\kappa_{\mathrm{II}}\left(\mathrm{Fe}_{3} \mathrm{Al}\right)$ and the lamellar $\kappa_{\mathrm{III}}$-phase $(\mathrm{NiAl})$. It is obvious that in areas with higher concentrations of $\mathrm{Al}, \mathrm{Fe}$, and $\mathrm{Ni}$, the amount of $\kappa$-phases is increased. At last, small $\kappa_{\mathrm{IV}}$ particles are precipitated $\left(\mathrm{Fe}_{3} \mathrm{Al}\right)$.

In Fig. 2, LOM and SEM-BSE images are shown, and by etching, the different phases are revealed. After etching with $\mathrm{FeCl}_{3}$, the microstructure is well contrasted and the $\mathrm{Fe}_{3} \mathrm{Al}$-based $\kappa$-phases $\left(k_{\mathrm{I}}, k_{\mathrm{II}}, k_{\mathrm{IV}}\right)$ are attacked more severely (Fig. 2a). Etching with $\mathrm{Cu}\left(\mathrm{NH}_{4}\right)_{2} \mathrm{Cl}_{4}$ colors the $\alpha$ and $\kappa_{\mathrm{III}}$ yellow and brown, in contrast $\kappa_{\mathrm{I}}, \kappa_{\mathrm{II}}$, and $\kappa_{\text {IV }}$ are bluish (Fig. 2b). In SEM-BSE images, the $\kappa$-phases are dark and the Cu-rich $\alpha$-phase is bright (Fig. 2c). The average Vicker's hardness is 160 HV5.

\section{First Heat Treatment at $950^{\circ} \mathrm{C}\left(1742^{\circ} \mathrm{F}\right)$ for $1 \mathrm{~h}$ and Cooling}

$\mathrm{NAB}$ sample T0 was heat treated at $950^{\circ} \mathrm{C}\left(1742^{\circ} \mathrm{F}\right)$ and quenched in water (fast cooling). According to the equilibrium diagram in Fig. 1, at $950^{\circ} \mathrm{C}\left(1742^{\circ} \mathrm{F}\right) \alpha$ - and $\beta$-phase exist, and the other alloying elements are dissolved. However, the 
FIG. 3 NAB microstructures after solution annealing and cooling. Sample $\mathrm{TO}=1 \mathrm{~h} 950^{\circ} \mathrm{C}$ and $\mathrm{H}_{2} \mathrm{O}$ cooling, Sample $\mathrm{T} 1=1 \mathrm{~h} 950^{\circ} \mathrm{C}$ and air cooling, LOM pictures after etching with $\mathrm{Fe}{ }_{3} \mathrm{Cl}$ and $\mathrm{Cu}\left(\mathrm{NH}_{4}\right)_{2} \mathrm{Cl}_{4}$ solutions, and SEM-BSE image.
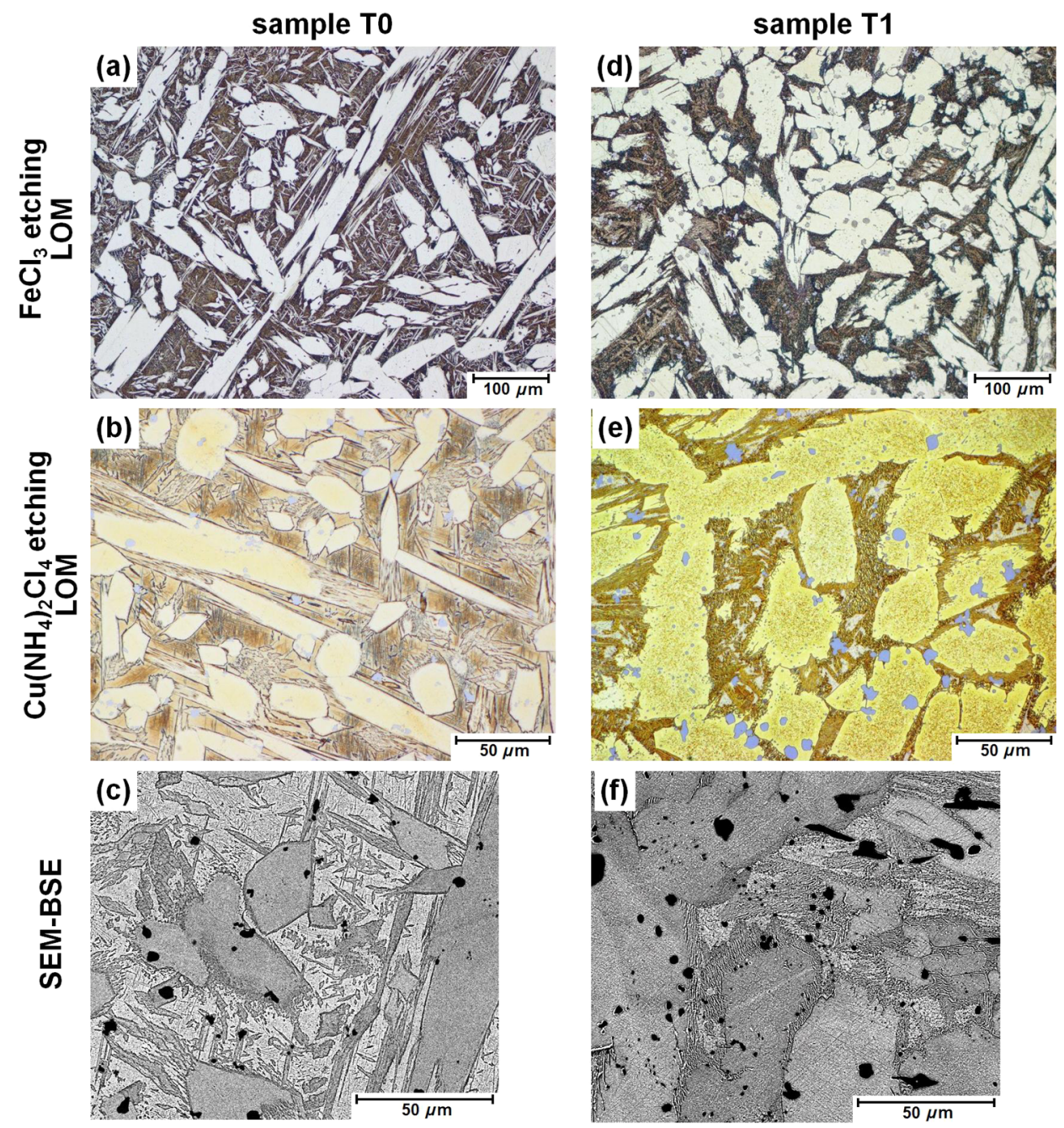

microstructures of sample T0 in Figs. 3 reveal that $\kappa_{\mathrm{I}}$, and $\kappa_{\mathrm{II}}$-phases were undissolved (Fig. 3a). Explanations for this are the short solution annealing time or deviation from the equilibrium diagram in Fig. 1. During quenching, the diffusion of the alloying elements is suppressed and $\beta$ is transformed to $\beta^{\prime}$, referred to as martensite (Fig. 3c). In the microstructure of T0 the coarse plate-like $\alpha$-phase is embedded in a fine-needled $\beta^{\prime}$-phase. $\kappa_{\mathrm{I}}, \kappa_{\mathrm{II}}$ (bluish, $\mathrm{Cu}\left(\mathrm{NH}_{4}\right)_{2} \mathrm{Cl}_{4}$ etchant) are visible in $\alpha$ - and $\beta^{\prime}$ phase, $\kappa_{\mathrm{III}}$ is present in fine-needled $\beta^{\prime}$-phase only (Fig. 3b). The $\kappa_{\mathrm{IV}}$ precipitates are not observed in the $\alpha$-phase any more. The average Vickers hardness is 232 HV5.

Sample $\mathrm{T} 1$ was heat treated at $950^{\circ} \mathrm{C}\left(1742^{\circ} \mathrm{F}\right)$ and cooled in air (slow cooling). The microstructure is similar to Sample AC. Again, $\alpha$ - and $\kappa$-phases but additionally $\beta^{\prime}$ are observed.

Coarse $\kappa_{\mathrm{I}}$ precipitates and finer $\kappa_{\mathrm{II}}$ are formed, and the lamellar $\kappa_{\mathrm{III}}$ is mixed with $\beta^{\prime}$. The lamellae of the $\kappa_{\text {III }}$ are finer than in Sample AC, which can be explained 
by a higher cooling rate in the smaller laboratory sample compared with an industrial ingot (Figs. $\mathbf{3 d}$ and $\mathbf{3 e}$ ). The amount of $\kappa_{\mathrm{IV}}$, is increased because during heat treatment an equalization of the alloying elements can take place caused by diffusion (Fig. 3f). Compared with Sample AC, an increase of the hardness from 160 to 183 HV5 was observed, which is attributed to finer $\kappa_{\mathrm{III}}$, the presence of $\beta^{\prime}$, and a higher amount of $\kappa_{\mathrm{IV}}$.

\section{Second Heat Treatment}

At first, the NAB samples $\mathrm{T} 2$ and $\mathrm{T} 3$ were heat treated at $950^{\circ} \mathrm{C}\left(1742^{\circ} \mathrm{F}\right)$ for $1 \mathrm{~h}$ and water quenched followed by a second heat treatment.

Sample T2 was heated to $700^{\circ} \mathrm{C}\left(1292^{\circ} \mathrm{F}\right)$, kept at this temperature for one day, and water quenched. According to the equilibrium diagram, the $\beta^{\prime}$-phase will

FIG. 4 NAB microstructures after heat treating the solution annealed and water cooled samples TO. Sample T2 $=1 \mathrm{~h} 950^{\circ} \mathrm{C} /$ $\mathrm{H}_{2} \mathrm{O}$ cooling +1 day $700^{\circ} \mathrm{C} / \mathrm{H}_{2} \mathrm{O}$ cooling, Sample $\mathrm{T3}=1 \mathrm{~h} 950^{\circ} \mathrm{C} / \mathrm{H}_{2} \mathrm{O}$ cooling +1 day $500^{\circ} \mathrm{C} / \mathrm{H}_{2} \mathrm{O}$ cooling, LOM pictures after etching with $\mathrm{Fe}_{3} \mathrm{Cl}$ and $\mathrm{Cu}\left(\mathrm{NH}_{4}\right)_{2} \mathrm{Cl}_{4}$ solutions, and SEM-BSE image.
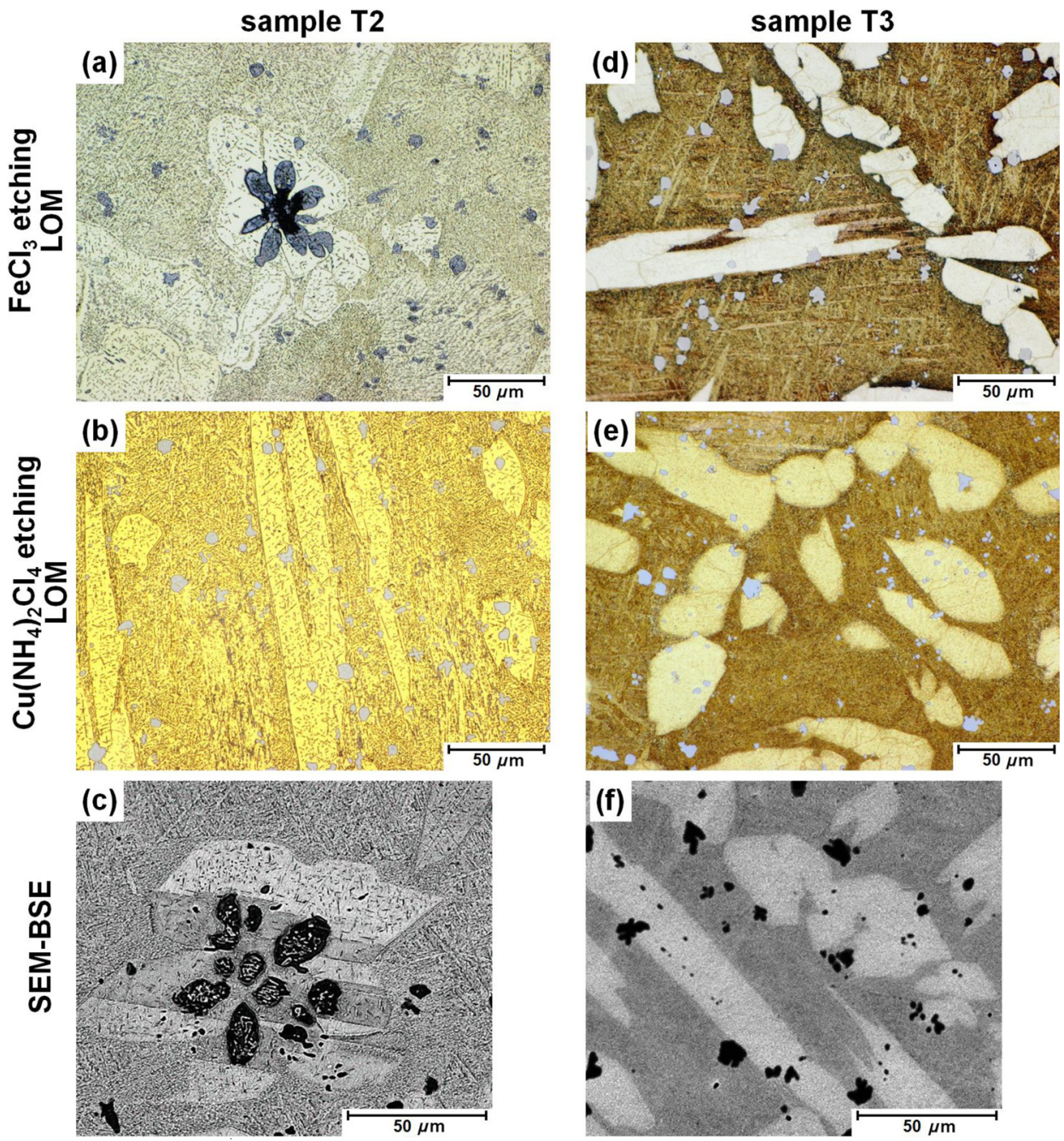
decompose to $\alpha$ - and $\kappa$-phases. After etching, $\kappa_{\mathrm{I}}$ and $\kappa_{\mathrm{II}}$ are well contrasted, they are colored bluish (Fig. 4a and $\mathbf{4 b}$ ). The typical morphologies for $\kappa_{\text {III }}$ (lamellae) and $\kappa_{\mathrm{IV}}$ phase (dots) are not observed (Fig. 4c), but in the large $\alpha$-grains, a high amount of fine needle-like precipitates are formed and it is impossible to identify the type of $\kappa$-phase, $\kappa_{\mathrm{III}}$ or $\kappa_{\mathrm{IV}}$. The irregular distribution of the "needles" can be explained by different concentrations of the alloying elements in the $\alpha$ - and $\beta$-phase during solidification of the NAB melt. Compared with sample T0, a decrease of the hardness from 232 to 197 HV5 was observed. Compared with Sample AC, an increase of hardness from 160 to 197 HV5 was observed.

Sample $\mathrm{T} 3$ was heated to $500^{\circ} \mathrm{C}\left(932^{\circ} \mathrm{F}\right)$, kept at this temperature for one day, and water quenched. After etching $\alpha-, \kappa_{\mathrm{I}}$-and $\kappa_{\mathrm{II}}$-phases are well distinguishable (Fig. $4 \mathbf{d}$ and $4 \mathbf{e}$ ). The precipitates of $\kappa_{\mathrm{III}}$ and $\kappa_{\mathrm{IV}}$ are very fine and cannot be identified explicitly (Fig. 4f). This important microstructural change results in a ca. $18 \%$ increase in hardness for sample $\mathrm{T} 2$ in relation to $\mathrm{T} 1$.

\section{ELECTROCHEMICAL CORROSION TESTS}

Typical results from potentiostatic corrosion testing in SSW are presented for material T0 in simulated sea water (SSW) in Fig. 5a. Qualitatively, potentiostatic data in SSW were similar for all materials and steady state currents were established within ca. $24 \mathrm{~h}$. After $70 \mathrm{~h}$, low anodic current densities, i.e., passive or inactive behavior, were established at the test potentials -211 and $-156 \mathrm{mV}_{\mathrm{SCE}}$. While the most negative potential $\left(-262 \mathrm{mV}_{\mathrm{SCE}}\right)$ caused just cathodic currents, the most positive potential $\left(-104 \mathrm{mV}_{\mathrm{SCE}}\right)$ resulted in 2 orders of magnitude higher anodic currents.

The current densities determined finally, after $70 \mathrm{~h}$ of testing, are presented in Fig. 5b for all materials. We may conclude for SSW, there is a sharp transition from passive to active behavior in the potential interval -156 to $-104 \mathrm{mV}_{\mathrm{SCE}}$ for all samples.

Samples T0 and T2, after corrosion testing in SSW at $+104 \mathrm{mV}$ for $70 \mathrm{~h}$, were selected and their cross sections were prepared for metallographic studies. The results are shown in Fig. 6.

Again, the microstructure of the heat treated T0 sample contains $\alpha$ - and $\beta^{\prime}$-phase. The $\beta^{\prime}$-phase is metastable and, in addition, contains higher amounts of $\mathrm{Al}$

FIG. 5 Potentiostatic measurements in sea water (SSW): (a) current density evolution of sample TO for different potentials and (b) final current densities for all samples after $70 \mathrm{~h}$.
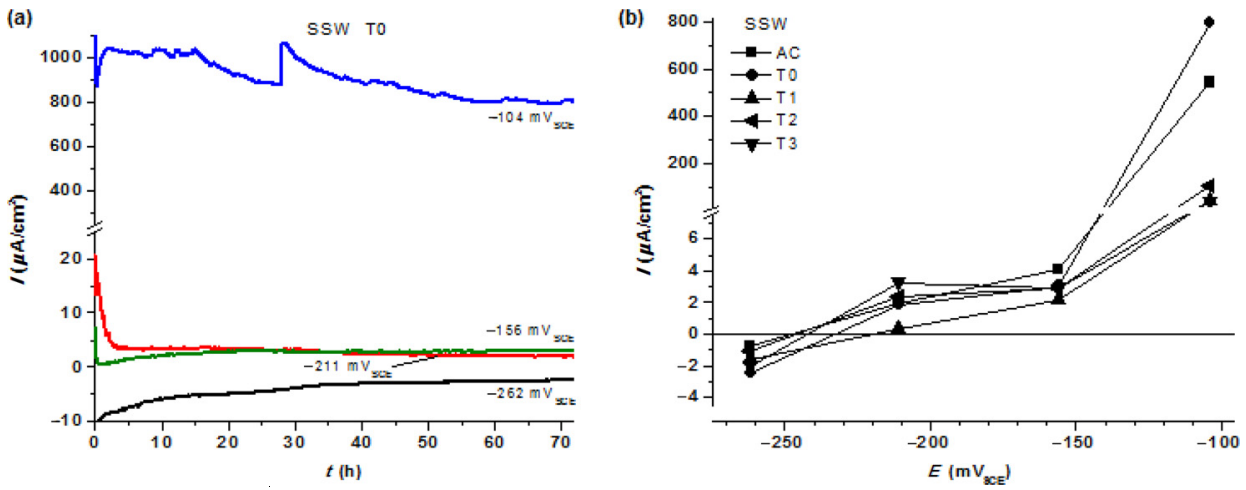
FIG. 6 Cross sections of samples TO and T2 after $70 \mathrm{~h}$ potentiostatic testing in SSW at $-104 \mathrm{mV}$ SCE. LOM pictures and SEM-BSE images.
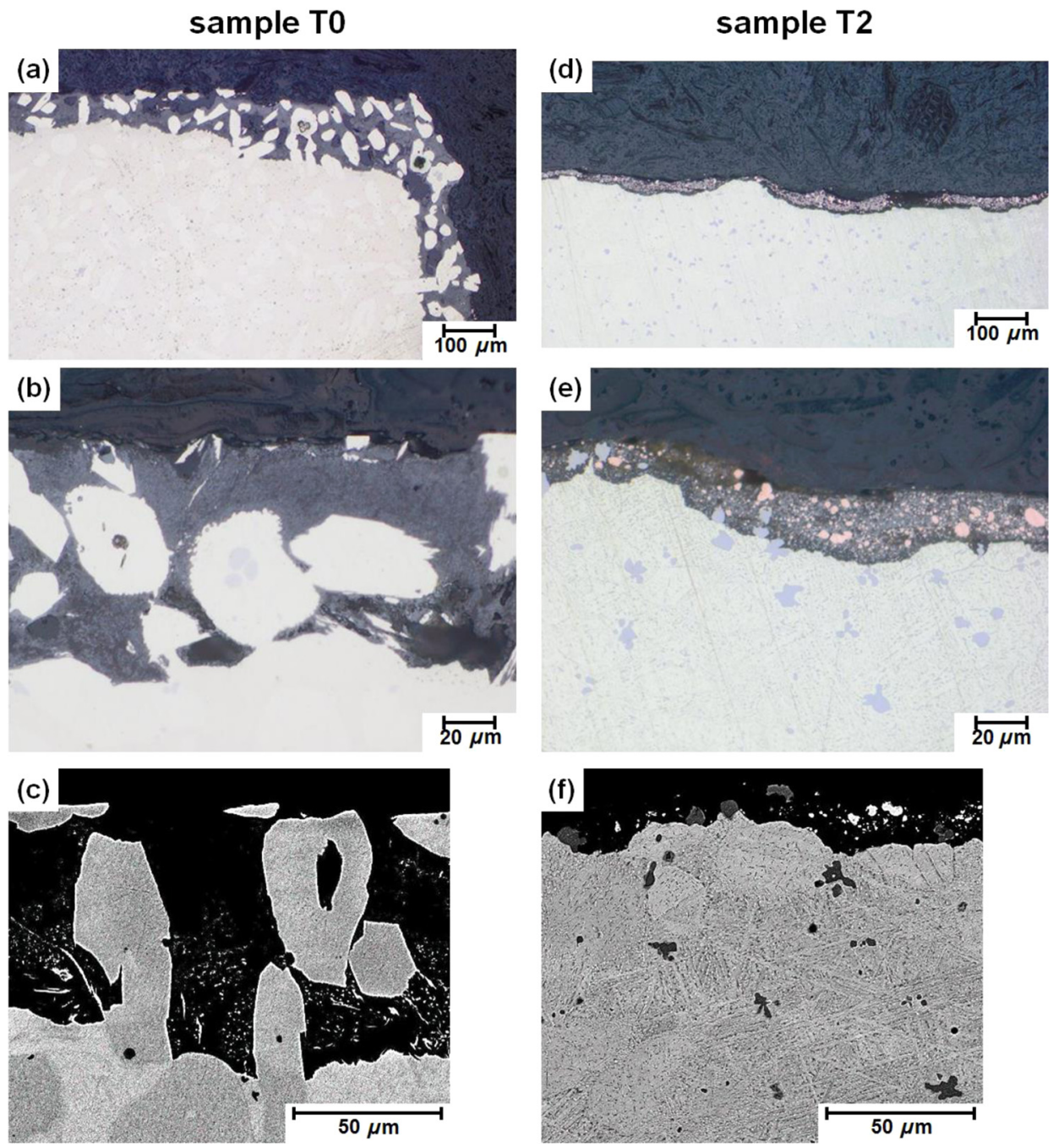

and Fe compared to the $\alpha$-phase. The images of the cross section show a dramatic change since the $\beta^{\prime}$-phase was selectively corroded, up to a thickness of $100 \mu \mathrm{m}$, while the $\alpha$-phase remained intact (Fig. 6a-6c).

Sample T2 was heat treated at $700^{\circ} \mathrm{C}$ and therefore the $\beta^{\prime}$-phase was decomposed into $\alpha$ - and $\kappa$-phases. By the absence of $\beta^{\prime}$, the local differences of electrochemical activities are balanced (Fig. $\mathbf{6 d - 6 f}$ ). The images of the cross section show a smaller and more localized corrosion attack. Metallic copper is observed within the corrosion products, indicating dealloying, and the $\kappa_{\mathrm{II}}$-phase remains unattacked (Fig. 6e).

In SFW, a very different reactivity of NAB was observed compared to SSW. A typical result from potentiostatic corrosion testing in SFW is presented for material T0 in Fig. 7a. At the lower test potentials, materials AC and T0 did not fully establish 
FIG. 7 Potentiostatic measurements in fresh water (SFW): (a) current density evolution of sample TO for different potentials, (b) final current densities for all samples after $70 \mathrm{~h}$.

(a)

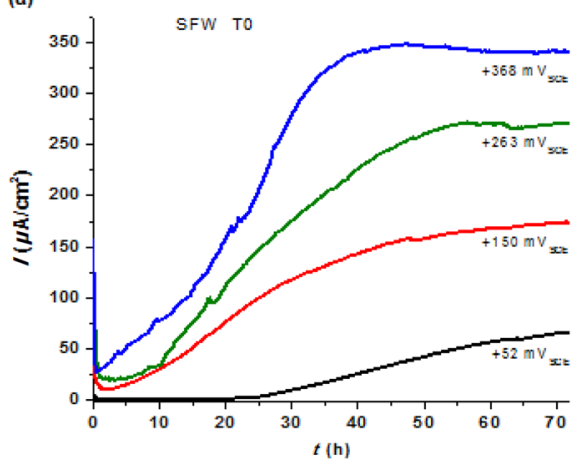

(b)

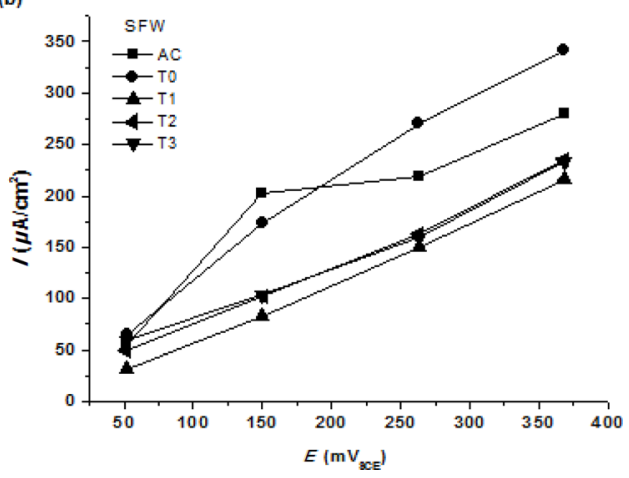

the quasi steady state after $70 \mathrm{~h}$, whereas the fastest was sample $\mathrm{T} 1$, which took ca. $48 \mathrm{~h}$. The current densities determined after $70 \mathrm{~h}$ of testing are presented in Fig. $\mathbf{7 b}$. There is no passive/active transition observed in the selected range of potentials, current densities of the materials increase rather proportionally with potential. However, the range of current densities of the different samples varies by a ratio of up to ca. 2:1, with lowest values established by T1.

Samples T0 and T2, after corrosion testing in SFW at $+368 \mathrm{mV}$ for $70 \mathrm{~h}$, were prepared for metallographic investigations. The results are shown in Fig. 8.

Based on the current densities observed in the potentiostatic tests, corrosion of T0 in SFW at $+368 \mathrm{mV}_{\mathrm{SCE}}$ was significantly less severe compared to SSW at -104 $\mathrm{mV}_{\mathrm{SCE}}$. For both samples, $\mathrm{T} 0$ and T2, shallow pitting was observed after $70 \mathrm{~h}$ testing. Again, the $\beta^{\prime}$-phase of sample T0 is more attacked than the $\alpha$-phase (Fig. $\mathbf{8 a}-\mathbf{8 c}$ ), while sample T2 exhibits no selective attack (Fig. 8d-8f).

\section{Conclusions}

The microstructure of a CuAl10Fe5Ni5 bronze is dominated by an inhomogeneous distribution of $\kappa$-phases in the $\alpha$-phase at room temperature. This effect is provoked during solidification of the melt when $\alpha$ - and $\beta$-phases are formed containing different amounts of alloying elements, which also have an inhomogeneous distribution.

When $\beta$-phase decomposes below $940^{\circ} \mathrm{C}\left(1724^{\circ} \mathrm{F}\right), \alpha$-phase and different $\kappa$-phases are formed. In this condition, NAB shows a high corrosion resistance against sea and fresh water.

After heat treatment at $950^{\circ} \mathrm{C}\left(1742^{\circ} \mathrm{F}\right)$ and water quenching the microstructure of the bronze changes and $\beta^{\prime}$-phase, also called martensite, is present beside $\alpha$-phase. Such a material corrodes severely, particularly in sea water, where the $\beta^{\prime}$-phase is attacked and the $\alpha$-phase remains, as was demonstrated by a potentiostatic corrosion test at an elevated potential.

All investigated samples exhibited passive behavior in synthetic seawater up to a critical potential in the interval -156 to $-104 \mathrm{mV}_{\mathrm{SCE}}$, above which active corrosion was observed. In contrast, in the bicarbonate/sulfate dominated synthetic fresh water used here, no potential range with stable passive behavior was observed. 
FIG. 8 Cross sections of samples TO and T2 after $70 \mathrm{~h}$ potentiostatic testing in SFW at $+368 \mathrm{mV}$ SCE. LOM pictures and SEMBSE images.
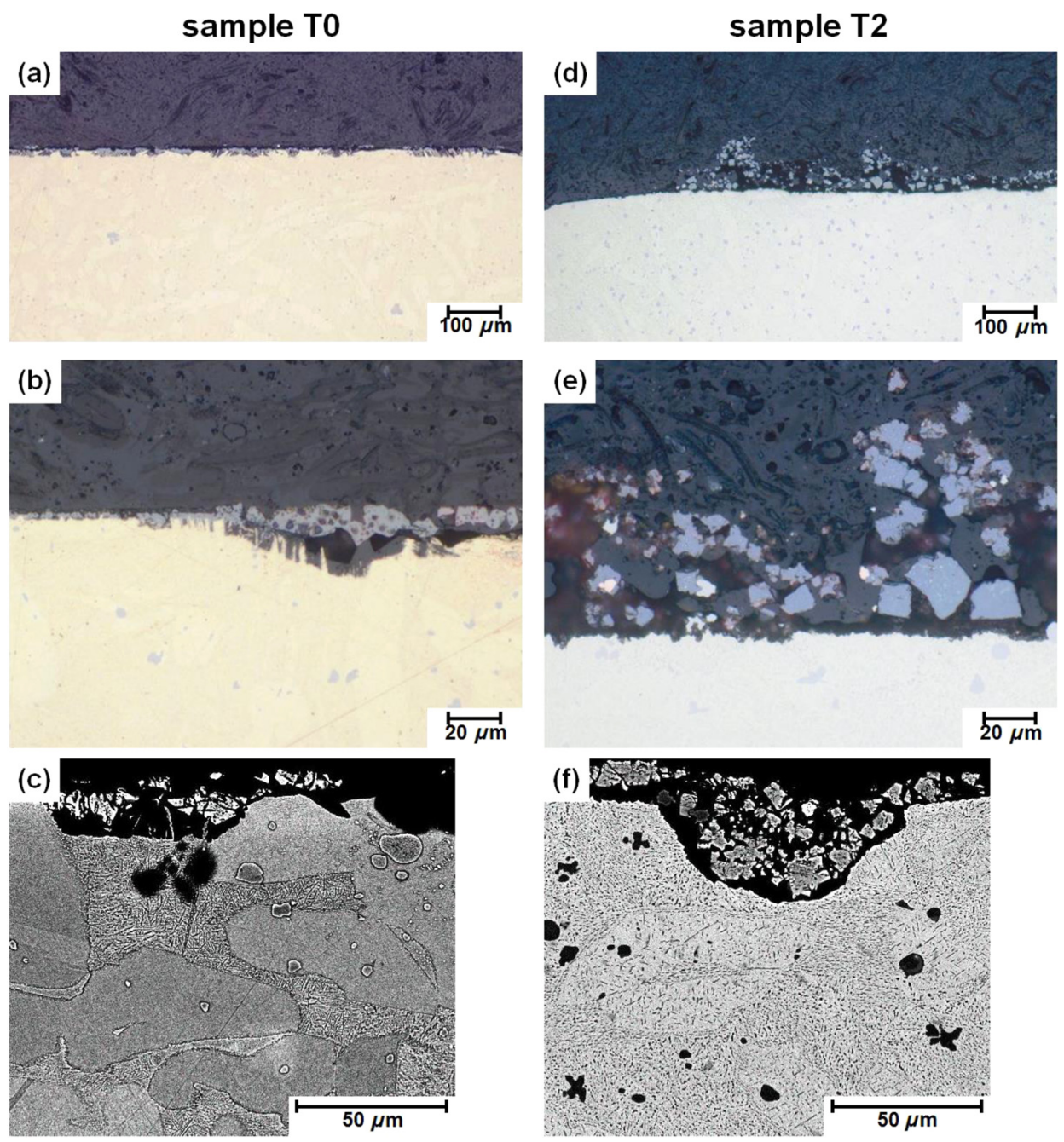

For practical applications, it appears important to prevent the formation of $\beta^{\prime}$-phase in NAB during thermal treatments. If $\beta^{\prime}$-phase formation is unavoidable, a post heat treatment between 500 and $700^{\circ} \mathrm{C}\left(932\right.$ to $\left.1292^{\circ} \mathrm{F}\right)$ is recommended since $\beta^{\prime}$-phase decomposes into $\alpha$ - and $\kappa$-phases, resulting in improved corrosion resistance.

\section{References}

[1] Deutsches Kupferinstitut, "Kupfer-Aluminium-Legierungen [CopperAluminum Alloy]," Informationsdruck i.6, Deutsches Kupferinstitut, Düsseldorf, Germany, 2010.

[2] Meigh, H., Cast and Wrought Aluminium Bronzes, Properties, Processes and Structure, IOM Communications Ltd., London, 2000. 
[3] Pisarek, B. P., "Model of Cu-Al-Fe-Ni Bronze Crystallization," Arch. Found. Eng., Vol. 13, No. 13, 2013, pp. 72-79.

[4] Hasan, F., Jahanafrooz, A., Lorimer, G. W., and Ridley, N., "The Morphology, Crystallography, and Chemistry of Phases in As-Cast Nickel-Aluminium Bronze," Metall. Trans. A, Vol. 13, No. 8, 1982, pp. 1337-1345.

[5] Culpan, E. A. and Rose, G., "Microstructural Characterisation of Cast NickelAluminium Bronze," J. Mater. Sci., Vol. 13, No. 8, 1978, pp. 1647-1657.

[6] Thomson, R. and Edwards, J. O., "The Kappa-Phase in Nickel-Aluminium Bronze, Part 2: Cast Microstructures and Properties," AFS Transactions, 1978, pp. 395-400.

[7] Brezina, P., "Heat Treatment of Complex Aluminium Bronzes," Int. Metals Rev., Vol. 27, No. 2, 1982, pp. 77-120.

[8] Wharton, J. A., Barik, R. C., Kear, G., Wood, R. J. K., Stokes, K. R., and Walsh, F. C., "The Corrosion of Nickel-Aluminium Bronze in Seawater," Corros. Sci., Vol. 47, No. 12, 2005, pp. 3336-3367.

[9] Culpan, E. A. and Rose, G., "Corrosion Behaviour of Cast Nickel Aluminium Bronze in Sea Water," Br. Corros. J., Vol. 14, No. 3, 1979, pp. 160-166.

[10] Vasanth, K. L. and Hays, R. A., "Corrosion Assessment of Nickel-Aluminum Bronze (NAB) in Seawater," presented at Corrosion 2004, New Orleans, LA, March 28-April 1, 2004, NACE International, Houston, TX, Paper No. 04294.

[11] Fonlupt, S., Bayle, B., Delafosse, D., and Heuze, J.-L., "Role of Second Phases in the Stress Corrosion Cracking of a Nickel-Aluminium Bronze in Saline Water," Corros. Sci., Vol. 47, No. 11, 2005, pp. 2792-2806.

[12] Al-Hashem, A. and Riad, W., "The Role of Microstructure of Nickel-Aluminium-Bronze Alloy on its Cavitation Corrosion Behavior in Natural Seawater," Mater. Character., Vol. 48, No. 1, 2002, pp. 37-41.

[13] Wharton, J. A. and Stokes, K. R., "The Influence of Nickel-Aluminium Bronze Microstructure and Crevice Solution on the Initiation of Crevice Corrosion," Electrochim. Acta, Vol. 53, No. 5, 2008, pp. 2463-2473.

[14] Linhardt, P., "Unusual Corrosion of Nickel-Aluminium Bronze in a Hydroelectric Power Plant," Mater. Corros., Vol. 66, No. 12, 2015, pp. 1536-1541.

[15] EN-1982, Copper and Copper Alloys - Ingots and Castings, British Standards Institute, London, 2008.

[16] Vander Voort, G. F., Metallography-Principles and Practice, 3rd ed., ASM International, Materials Park, OH, 2004.

[17] Linhardt, P., Kührer, S., Ball, G., and Biezma, M. V., "Design of a Multichannel Potentiostat and Its Application to Corrosion Testing of Nickel Aluminium Bronze," (unpublished). 